\title{
EBNA-1 inhibitor VK-2019
}

National Cancer Institute

\section{Source}

National Cancer Institute. EBNA-1 inhibitor VK-2019. NCI Thesaurus. Code C159410.

An orally available, small molecule inhibitor of Epstein-Barr nuclear antigen 1 (EBNA-1) with potential antineoplastic activity. Upon administration, EBNA-1 inhibitor VK-2019 binds to EBNA-1 and inhibits EBNA-1 DNA binding activity. This disrupts the replication, maintenance and segregation of the Epstein-Barr virus (EBV) genome, which may lead to tumor cell death in EBV-associated malignancies. EBNA1, a sequence-specific DNA binding protein, plays an important role in EBV episomal genome maintenance and gene transactivation. 